\title{
TTR
}

Traduction, terminologie, re?daction

\section{Transferring Culture in Translations - Modern and Postmodern Options}

\section{Klaus Peter Müller}

Volume 8, numéro 1, 1er semestre 1995

Orientations européennes en traductologie

URI : https://id.erudit.org/iderudit/037197ar

DOI : https://doi.org/10.7202/037197ar

Aller au sommaire du numéro

\section{Éditeur(s)}

Association canadienne de traductologie

ISSN

0835-8443 (imprimé)

1708-2188 (numérique)

Découvrir la revue

\section{Citer cet article}

Müller, K. P. (1995). Transferring Culture in Translations - Modern and Postmodern Options. TTR, 8(1), 65-83. https://doi.org/10.7202/037197ar

\section{Résumé de l'article}

Le transfert de culture en traduction - Options modernes et postmodernes Cet article présente les éléments caractéristiques des théories modernes de la traduction de Charles Baudelaire et de Sigmund Freud dans le contexte de la reconnaissance et de la traduction des différences de culture et de compréhension. Les traductions dépendent d'une certaine homogénéité (entre les différents systèmes de signes utilisés) qui peut être obtenue par la création du sens au moyen du langage. La compréhension, la reconnaissance et la création du sens sont essentiels à la traduction. Baudelaire tout autant que Freud sont tout à fait conscients de la valeur relative du sens. Avec les théories postmodernes, la traduction devient « nécessairement impossible ».

L'utilisation pratique que font Paul de Man et Jacques Derrida du texte de Walter Benjamin sur la traduction montre en effet qu'ils ne le traduisent pas. En fait, ils l'adaptent à leur propre perspective et au sens spécifique qui est le leur. On peut certes détecter une pluralité de sens différents chez Benjamin et on doit reconnaître la nécessité d'en réaliser des traductions multiples et ambiguës, mais des traductions qui ne soient pas entièrement arbitraires. Seule une combinaison significative et inventive de sa propre position et de la position de l'autre peut rendre possible le transfert culturel, la reconnaissance et la compréhension exploratoire de l'altérité.
Tous droits réservés @ C TTR: traduction, terminologie, rédaction — Les auteurs, 1995
Ce document est protégé par la loi sur le droit d'auteur. L'utilisation des services d'Érudit (y compris la reproduction) est assujettie à sa politique d'utilisation que vous pouvez consulter en ligne.

https://apropos.erudit.org/fr/usagers/politique-dutilisation/ 


\section{Transferring Culture in Translations - Modern and Postmodern Options}

\section{Klaus Peter Müller}

No discussion about the relationship of modern and postmodern thinking in the realm of translation can take place without reference to the controversy in the 17th and 18th century over the moderns and the ancients, which is generally called "Querelle des Anciens et des Modernes" (Perrault, 1964). One interesting point emerges here: From the very moment when the modern period began to be held in greater esteem, history and the historically determined differences were also regarded more positively. So when one says that with Friedrich Schlegel translation finally and definitely obtained a "historic-dynamic significance ${ }^{1}$," this implies both a very high esteem for translation, an acknowledgement of its value, and a recognition of its dependence on historical circumstances; thus, an acceptance of its relativity. From that moment, a translation is no longer just an eternally thwarted attempt at imitating an ideal original text, but, on the contrary, it is an achievement in at least two respects: it brings about the survival of the original, and it makes people aware of the differences between the ancient and the modern, or the strange (as well as foreign) and the known, familiar qualities. A translation thus furthers a greater awareness of one's own position, especially in comparison with the otherness of the source text, and in this way it promotes an understanding both of one's own cultural identity and of the other. Such a high esteem of

1. My translation of Apel (1982), p. 97. All subsequent translations will also be mine. 
the other(ness) and of the historically determined differences has been a crucial element in modern thinking from its very beginning (Schlegel, 1928; Apel, 1982, pp. 89-98; Perrault, 1964).

Transference of culture can be best achieved on such a basis of differentiation, heightening of awareness, and pinpointing specific cultural features (Snell-Hornby, 1988, pp. 39-64; Williams, 1981, p. 13; Müller, 1986). The question to be raised (and partly answered) now is: What are the particularly characteristic options provided by modern and postmodern thinking for transferring culture in translations? This implies questions about the specific otherness of the foreign culture, the objectives to be obtained by translations, and the epistemological and semiotic concepts involved.

The following authors have been selected to provide representative insights into this problematic field: 1 . Charles Baudelaire, as a widely acknowledged theorist of modernity and as a poet and translator. 2. Sigmund Freud, as the theorist and practitioner of dream interpretation, i.e. an area where translatory work is of fundamental importance, and also as a critical observer of culture. Baudelaire and Freud are generally acknowledged representatives of modern thinking. 3. The position of the third author to be discussed, Walter Benjamin, is more equivocal, and is also dependent upon the subject of his investigations: his analyses of contemporary society and of art are seen to be modern; his discussions of language and translation, on the other hand, are full of romantic and cabalistic ideas. At the same time, his thoughts are affiliated to postmodern theories. Thus, Paul de Man's and Jacques Derrida's interpretations of Benjamin's "Aufgabe des Übersetzers" ("The Task of the Translator") will be used to describe postmodernism and its main differences to modern theories of translating and transferring cultures.

1. Charles Baudelaire: Art as a Translation of the Eternal into the Temporal, or Translation as the Art of Finding One's Own (Cultural) Identity in the Other. The famous "Querelle des Anciens et des Modernes" was mostly concerned with attributing greater significance to either side. Baudelaire was far less interested in such 
problems of evaluation or progress, but rather in the description and definition of a new experience of life. He said that the tradition which had provided human life with relevant standards and values had been destroyed, and a new basis for such values had not yet been established ${ }^{2}$. Thus, the present for him was characterized by a combination of oppositions that was also typical of art: "La modernité, c'est le transitoire, le fugitif, le contingent, la moitié de l'art, dont l'autre moitié est l'éternel et l'immuable." (Baudelaire, 1971, II, p. 150) Such a combination of oppositions is again and again characteristic of modernity. One can, in fact, say that modernity is above all marked by the dialectic principle of combining opposites ${ }^{3}$. For Baudelaire (as for Hegel and Marx) modern life is connected with a high esteem for reason, for artfulness, and for conscious creation. Nature is seen rather negatively. The good and the beautiful are taken to be always the result of art. Therefore, art is not meant to imitate nature ${ }^{4}$.

Truth in this concept of art is multidimensional, but not ambiguous. Art wants to reveal the complexity of this truth. A

2. Baudelaire $(1971, \mathrm{I})$, p. 252. On "progress", see p. $381 \mathrm{f}$. Also Perrault (1964).

3. See also Baudelaire (1971, II), p. 137: "La dualité de l'art est une conséquence fatale de la dualité de l'homme," and I, p. 253; I, p. 307; II, p. 136. Borgal (1961, p. 102) speaks of the "éternelle dialectique" of the poet; also Béatrice Didier's notes in Baudelaire (1972, p. 258). Marx's dialectics and interpretations of his value theory as an attempt to "make rules of translating explicit" can only be referred to here in passing. Cf. Habermas (1988, II, pp. 494-498), the quotation is from p. 495.

4. Baudelaire (1971, II), pp. 179-183. This attitude to art and nature is typically modern. The negative qualities of the "natural" state of things are similarly described in Hegel (1970), pp. 58f.

5. Baudelaire (1971, I), p. 141: "La vérité, pour être multiple, n'est pas double." See also I, pp. 197-200; I, p. 253. 
representation of this relative truth is also the objective of translation. Idiosyncracies of the language, the rhythm or structure of the source text are of secondary importance only, and may, if necessary, be neglected ${ }^{6}$. Translation is an art, not a natural process. And art is also a translation, because it translates the beautiful and the truth from memory and from eternity into concrete temporality, it transfers the super-natural ("le surnaturel") into the artfulness of the present. In doing so, it must, however, avoid mere imitation?

Translations should not be imitative either. Like all art, they, too, in their special way, want to convey an idea of truth and beauty. Baudelaire's translations of Edgar Allan Poe, for instance, try to transfer the American's imaginative, intellectual and spiritual world into French. What is being translated, therefore, is that which is regarded as the essential truth. Baudelaire once expressed this in the following way: "La musique donne l'idée de l'espace. Tous les arts, plus ou moins; puisqu'ils sont nombre et que le nombre est une traduction de l'espace." (1971, II, p. 386)

Translation for Baudelaire is thus not yet defined intralinguistically, it is not a relation between one linguistic function and another, but it is rather a relation between a subject and an object, or between a world of ideas on the one hand and its linguistic representation on the other ${ }^{8}$. In his translations, Baudelaire is

6. Borgal (1961), p. 118: "Les artifices du rythme, déclarent les Notes nouvelles sur Edgar Poe, sont un obstacle insurmontable à ce développement minutieux de pensées et d'expressions qui a pour objet la vérité."

7. Baudelaire $(1971$, l), p. 198: "l'art est une mnémotechnie du Beau: or, l'imitation exacte gâte le souvenir."

8. Paul de Man, "Introduction," in Hans Robert Jauß, Towards an Aesthetics of Reception (Minneapolis, Univ. of Minnesota Press, 1982): "'translation is per definition intra-linguistic, not a relation between a subject and an object, [...] but between one linguistic function and another." (Quoted from Chase, 1985, p. 64.) 
concerned with preserving a certain signified by means of another system of signifiers. He does not see himself as being involved in completely replacing one sign system by another. Analyses of his translations tell us that he ultimately looked for, found and translated his own (cultural) identity in and from the foreign texts 9

2. Sigmund Freud: The Translation of the Unknown into the Ego, or The Meaningful Differentiation of the Subject. In Paul Ricœur's interpretation of Freud, psychoanalysis is an "Archaeology of the Subject." It induces a hermeneutic process which is concerned with "demystification and a dismantling of illusions." According to Ricœur, it is Freud's intention to reveal consciousness as false, "in order to obtain an authentic language by means of interpretation." So there is a truth here as well, to be detected in the sometimes deformed signs of language and dream imagery. But Ricœur is keen to point out the relativity of this truth: "Seeing that Freudianism is a discours on the subject and recognizing that the subject is never that which is spoken of, these two are one and the same thing." And he continues: "It is a fact that Freud dismisses any thought of a pure initial subject ${ }^{10}$."

There is, therefore, no absolute truth and no definite identity of the subject. Freud's psychoanalysis is, on the contrary, characterized by a differentiation of the subject which goes along with a differentiation of specific sign systems. Signs of the preconscious and the unconscious are combined in a dream which is the fulfilment of a particular wish. This makes the dream a specific "place of meaning" ("Ort des Sinns"). The "interpretation of the signs of the wish" is a translation, a transferring of this place

9. Pia (1958), p. 32: "One can hardly imagine a more subjective author. He only translated Poe, because he recognized himself in the poet from Baltimore." See also Lemonnier (1928).

10. Ricœur (1974), pp. 429-469. The quotations are from p. 430. 
and its meaning into the place of meditation and "reflection," into the "conscious meaning of speech" or discourse".

The dream work "translate[s] the unconscious wish fantasy into the code language of the manifest dream." (Olsen \& Koppe, 1988 , p. 157) The dream interpretation tries to (re-)translate that which is unconscious (and as yet unknown) into the "conscious meaning of speech." There is thus a translation of one sign system (of the pre- and unconscious) into another, namely that of consciousness. Different sign systems can, therefore, be distinguished within one human being. Ultimately, however, they form a complementary unity. They can only be interpreted and understood because of their translatability which is based on a common meaning. This translatability, respectively, this meaning, is the basis and prerequisite of understanding. Translatability and meaning are brought about by the differentiated unity of human beings which provides the context and frame for understanding and significance. An appropriate inversion of this conclusion would be to say that nothing can be translated (or understood, or even noticed) when it is wholly outside and different from the translator's life.

For Freud, the dream is the prototype of "all hidden, substituted and fictitious expressions of human wishes." That is why his psychoanalysis is "at the very centre of the great contemporary debate about language." (Ricœur, 1974, p. 17) The dynamics "of the wish and of repression can only be shown semantically": "drives," Ricœur says, "[...] can only be understood through 'meanings.' This is the real basis of all analogies between dreams and jokes, dreams and myths, dreams and works of art." (p. 18)

This concept of meaning and semantics is fundamental for the question of translatability. Signs are translatable as long as they are meaningful, and vice versa:

11. Freud (1977), pp. 110-119, for the dream as wishfulfilment. See also Ricœur (1974), p. 434 and Stephan (1989). 
as remote as the primary expressions of the basic drives, and as deformed as the derivatives of these expressions may be, they still belong to the sphere of meaning; and basically they can be translated into terms of consciousness. In short, psychoanalysis makes a return to consciousness possible, because the unconscious is in a certain way homogeneous to consciousness; it is the relative other of consciousness, not its absolute other [it is only relatively different, not absolutely different]." (p. 440)

Translation is thus possible in psychoanalysis because of this homogeneity, because of the fact that there are similarities, that there is a common context which combines differences in a specific, perhaps dialectic way. It is also obvious that what has been translated is always only of relative and never of any absolute value. But the translation brings about a "new quality of consciousness." This is possible when the 'old' consciousness opens up to what is new, different and foreign, which it can understand and, perhaps, assimilate through its homogeneity. What is in fact taking place in this way is a typical hermeneutic process.

This process, as well as any dream interpretation and translation, is not endless and need not be stopped arbitrarily, but it comes to an end where "particular configurations can be detected," as one "regularly encounters the same significant segments, the same correspondences of meaning." In other words, a structure is being created (very similar to the way this is done in Lévi-Strauss's structural anthropology and A. J. Greimas's semiotics ${ }^{12}$ ), a structure "which both justifies and presupposes the analysis" ( $p$. 443). Again Ricœur emphasizes the relativity of the result: "The reality of the unconscious is not an absolute one, but is wholly relative to the operations which provide it with meaning." (p. 446)

Why is all this important for the problem of 'transferring culture'? Because for Freud, as for Hegel and also for a number of postmodern thinkers, "a culture is created by the dynamics of basic

12. Lévi-Strauss (1971); Greimas (1970). See also Sturrock (1986), pp. $122 f$. 
drives" (p. 476). In this process of creating culture, the unconscious is "the system of the key signifiers which have existed from the very beginning" (p. 479).

Freud and Ricœur reveal to what extent an understanding of culture is dependent upon an understanding of meaning, i.e. of something that is created and established by language rather than by any other material things. In literature this "mysticism of creation" is particularly prominent, this vigour of meaningful lives, which for Ricœur is usually dialectic (p. 563). Like myth, literature is "the symbolic investigation of our relationship to essential being, to essence," i.e. to meaning (p. 564). Meaning (and thus a foreign culture) is understandable, recognizable and translatable, because (and only when) it is represented in signs which convey certain significant structures, and because (and when) there is a homogeneity between the different sign systems used. ${ }^{13}$

3. Walter Benjamin and Postmodernism: Translation as Historical Reference to the Eternal, or The Necessity of Translation as Its Impossibility. Walter Benjamin's concept of translation also includes myth, meaning and a transferring to some common ground. This common ground, however, cannot be structurally verified or even clearly described, because it is always connected with something numinous. This is the "language of truth - the true language," which, however, does not intend to convey a particular meaning, but "the essential," "the unfathomable, the mysterious, the 'poetic.'" This true language "contains the ultimate secrets, with which all thinking is concerned, effortlessly and silently" (Benjamin, 1972, pp. 16, 9). The pure language can be revealed or produced by neither an original text, be it poetic or religious, nor by a translation. Only a translation, however, can "represent" this absolute truth, "by realizing it in the bud or intensively" (p. 12). For two interrelated reasons Benjamin regards translations as absolutely necessary and positive: one reason, which may be termed "'suprahistorical'"

13. On the relationship between psychoanalysis and translation see also Benjamin (1989 and 1992). 
(Benjamin, 1989, pp. 92f), maintains that the eternal objective of human life is to come close to the divine origin; the other reason underlines the historical aspect and confirms that translations reveal how close to or far from that eternal aim human beings are at a certain time in history.

The "task of the translator" is - consistent with the first reason - "to release that pure language that is bound in a foreign tongue in one's own language." In accordance with the second reason, translation at the same time raises the awareness of historical changes:

[Translation] is far from being an empty equation of two dead languages; it is rather the most appropriate of all genres for reflecting the ripening of the foreign language, and the labouring and perpetual renewal of one's own. (Benjamin, 1972, p. 13)

Thus the translator is necessarily particularly aware of historical developments and changes in and by language. Language, however, is for Benjamin not a "'tool, means, or medium,'" but "an end in itself." Accordingly, truth is "not produced subjectively," but it is "given." It is also never relational, and, therefore, never relative ${ }^{14}$.

Benjamin's concepts of language and translation are, therefore, not suited for any theory of translation which a) regards language as an organon; b) sees language, its function and truth as being dependent upon human beings and social conventions; c) emphasizes the conveyance of meaning and information; d) is related to a concept of communication.

14. Tiedemann (1973), pp. 49-51. See also p. 48: The "alternative of convention or mimesis has become redundant; in its place Benjamin's theory of language offers a theory of translation. Producibility [...] is embedded in the linguistic potential of things, as their idea. [...] The idea is the meaning of these things which does not yet exist, but is coming into existence; it is that towards which the things are moving, but which they can only become by being translated and represented." 
As for transferring culture, Benjamin is also ambivalent: on the one hand, he wants to dissolve the idiosyncracies of both the foreign and the domestic cultures in their common ground, i.e. in pure language; on the other hand, he maintains that the source text should influence and enrich the target language.

Benjamin certainly clearly points out the dangers of too much subjectivity, and he underlines the relativity of translations. His aesthetics as well as his theories of language and translation never allow man to be a "demiurge ${ }^{15}$."

Benjamin's critical attitude toward the subject and his emphasis on the relativity of translations have made his theories interesting for postmodern thinkers. What is conspicuous about their interpretations, though, is the fact that they often are not compatible with Benjamin's writings, or that they emphasize only one element very strongly. This is, for instance, the case with Paul de Man who quickly and unjustifiably asserts that Benjamin says translation is impossible ${ }^{16}$. De Man continues by arguing at great length that the translator inevitably and always fails, which is also not what Benjamin asserts. Ultimately all history is a failure for de Man: "Now it is this motion, this errancy of language which never reaches the mark, which is always displaced in relation to what it is meant

15. Tiedeman (1973), p. 69. Apel (1982), pp. 177-192, shows how Benjamin's translations of Baudelaire come close to his theory. Benjamin, he says, does not translate content matter, but rather Baudelaire's way of speaking and thinking. At the same time it becomes apparent (very similar to what was said above concerning Baudelaire's translations of Poe) that in Benjamin's translations of Baudelaire there is always a special admixture of Benjamin's individuality (p. 178).

16. De Man (1986), p. 74. Quite a different point of view is put forward by Apel (1982), p. 97, who maintains that Benjamin's concept of "'translatability" is based on the very fact that "classical texts require endless criticism." 
to reach, it is this errancy of language, this illusion of a life that is only an afterlife, that Benjamin calls history ${ }^{17}$."

De Man's interpretation leaves out all the positive aspects of translation and pure language that are contained in Benjamin's text, and it one-sidedly emphasizes references to negativity, foreignness, non-identity and fragmentation. In short, it underlines the otherness in Benjamin, which is, however, at the same time precisely de Man's own otherness and that which is proper to himself and to his identity as a postmodernist.

Similar things can be said about Jacques Derrida. In his essay "Des Tours de Babel" (1985) he clearly states from the very beginning and maintains again and again that understanding something unequivocally is a reduction of multiple meaning to a single structure and a definitive meaning. The key word in the first paragraph of his essay, and one can safely say of the entire text (as of most of Derrida's whole work), therefore, is "multiplicity." The text, after all, is not about a single, definite tower of Babel, but about an indefinite number of towers, and the title also calls to mind a "detour" (Fr. "détour"), which, in this case, does not lead to one particular destination, but to multiplicity (and even to "a pas de sens," which is full of meaning) ${ }^{18}$.

17. De Man (1986), p. 92. De Man continues: "As such, history is not human, because it pertains strictly to the order of language; it is not natural, for the same reason; it is not phenomenal, in the sense that no cognition, no knowledge about man, can be derived from a history which as such is purely a linguistic complication; and it is not really temporal either, because the structure that animates it is not a temporal structure."

18. Derrida (1985a), p. 204, and, for the title of this chapter, p. 171: "This story [i.e. the story of Babel, but what is said about it equally applies to Derrida's own text and story] recounts, among other things, the origin of the confusion of tongues, the irreducible multiplicity of idioms, the necessary and impossible task of translation, its necessity as impossibility." 
This fundamental, irreducible multiplicity is the most crucial problem of translation and of understanding, and it is the reason why both are ultimately impossible, or why it is, at least, impossible to ever come to an end of translating and understanding ${ }^{19}$. Whenever one selects just one structure, and, therefore, a single meaning, it is similar to a proper name and becomes "almost untranslatable" (Derrida, 1985a, p. 165). The untranslatability of one's own identity, or of a closed sign system, can thus only be overcome by the other, i.e. by an opening of the system and an exchange with something outside that system, something different ${ }^{20}$.

But in spite of this insight, and even though, occasionally, for Derrida translation is an interpretation by semantic equivalents, and though he knows that reading and trying to understand a text is a translation, and even though he translates himself, as in this case Benjamin's text on translation, he never finds identity and unity, but, in accordance with his concept of language and history, only heterogeneousness and otherness, "différance," "dissémination," "multiplicitéé."

19. Derrida (1985a), p. 165: "the irreducible multiplicity of tongues;" "it [the "'tower of Babel'] exhibits an incompletion, the impossibility of finishing, of totalizing, of saturating, of completing."

20. Derrida (1985a), p. 177: "being proper and thus untranslatable."

21. Derrida (1985a), p. 172: "to be translated, in other words, interpreted by its semantic equivalent." On translation as reading and understanding, see pp. 166, 175ff, 191, 195. On history and language, which are both seen to be without subjects: Derrida (1967), pp. 425ff; Derrida (1976a), pp. 21, 93-103; Derrida (1976b), pp. 10ff. See also Derrida (1979 and 1985b). Chase (1985), pp. 79f, states that Derrida's "prosthesis," the "adding of artificial parts that remarks and perpetuates a disfiguration," the practice of "adding artificial organs to supply a deficiency," is the process of translation, "of the surgically intrusive, rigorously 


\section{A Brief Evaluation of the Options Offered}

The danger in seeing difference and otherness as absolutely fundamental is twofold: Either understanding and translating become totally impossible, or the otherness is made identical with one's own (cultural) identity. It must be said, therefore, that in postmodern thinking, language obtains an ahistorical function dissolving all specific social, regional and temporal contexts ${ }^{22}$. This danger can never be underestimated, and in the context of transferring culture it means that the particular otherness of a foreign culture cannot even be recognized ${ }^{23}$.

When postmodern thinking is praised for having done good service to translators by devaluing the source text and its author, by pointing out the relativity of meanings and sign structures, by putting the signifier above the signified, by granting translations greater freedom and by emphasizing differences, it must be pointed out that all these aspects have been part of modern thinking from its very beginning. This basic complexity of modernity which combines universal with very particular elements, and that which is specifically one's own with what is strange and foreign, should be

abusive translation that replaces one device with another."

22. Venuti (1992), pp. 8f: "Whatever meaning may be assigned to Benjamin's notion of 'pure language,' both Derrida and de Man construe it according to the poststructuralist concept of language as a differential plurality [...]. As a result, the post-structuralist concept of language is assigned a suprahistorical status, and each translated text is allegorized as a transcendental 'errancy of language,' removed from its particular social and historical circumstances."

23. Problems of translating from a totally different or unknown world are also discussed in Quine (1960), Putnam (1979), pp. 77-80, and Markis (1979). Interestingly enough (cf. footnote 3), Markis underlines the need for a "'dialectic' philosophy of translation" (1979, pp.211f, 280). 
kept in mind. Because it is only in this way that an understanding, a positive acceptance of the otherness of a foreign culture and its translation become possible. Only thus can responsible social, political and translatory work justifiably be performed.

Postmodern thinking emphasizes only one aspect of modernity, namely difference. Its counterpart, sameness, is either not explicitly mentioned or unfavourably presented. Without this sameness, and without its more prominent equivalent terms, "identity" and "subject," however, the whole movement would lose all its impetus. We still cannot avoid being concerned with the subject, with its and our history and meaning. We are still subject to ourselves (as is endlessly documented at every congress and with each publication), hopefully without being solipsistic, and, therefore, we are still modern ${ }^{24}$. Accordingly, translation cannot be "the locus of difference" only (Venuti, 1992, p. 13), it must rather, especially when it emphasizes differences, also demonstrate its own position, its identity, history, and meaning. Only then is a transferring of cultures possible.

Dr. Klaus Peter Müller, Universität Düsseldorf, Anglistik, Universitätsstr. 1, D-40225 Düsseldorf.

\section{References}

APEL, Friedmar (1982). Sprachbewegung: eine historisch-poetologische Untersuchung zum Problem des Übersetzens. Heidelberg, Winter.

24. Meschonnic (1992): "Modernity is a battle. Endlessly beginning again. Because it is a nascent state, indefinitely nascent, of the subject, of its history, of its meaning. [...] Wanting to know what modernity is, I realized that it is the subject as ourselves [en nous]" (p. 401). 
BAUDELAIRE, Charles (1971). Écrits sur l'Art (ed. Yves Florenne). Paris, Livre de Poche (2 vol.).

(1972). Mon cour mis à nu. Fusées. Pensées éparses (ed. Béatrice Didier). Paris, Livre de Poche.

BENJAMIN, Andrew (1989). "Psychoanalysis and Translation," in A. Benjamin, Translation and the Nature of Philosophy. A new Theory of Words. London, Routledge, pp. 109-149.

(1992). "Translating Origins: Psychoanalysis and Philosophy" in Venuti, ed. (1992), pp. 18-41.

BENJAMIN, Walter (1972). "Vorwort zu Charles Baudelaire, Tableaux parisiens," in W. Benjamin, Gesammelte Schriften (ed. Tillman Rexroth). Frankfurt, Suhrkamp (vol. IV, I), pp. 9-21.

BORGAL, Clément (1961). Charles Baudelaire. Paris, Éditions Universitaires.

CHASE, Cynthia (1985). "Paragon, Parergon: Baudelaire Translates Rousseau," in Graham, ed. (1985), pp. 63-80.

DERRIDA, Jacques (1967). L'Écriture et la différence. Paris, Éditions du Seuil.

Ullstein.

(1976a). Randgänge der Philosophie. Frankfurt, (1976b). OfGrammatology.Baltimore, Johns Hopkins. Original: De la grammatologie (1967), Paris, Minuit.

(1979). "Living On," in J. Derrida, Deconstructionand Criticism. New York, Continuum, pp. 75-176.

(1985a). "Des Tours de Babel," in Graham, ed. (1985), pp. 165-205. (Originally in Annie Cazenave and Jean-Francois 
Lyotard, eds. [1985]. L'Art des confins. Mélanges offerts à Maurice de Gandillac. Paris, Presses Universitaires de France, pp. 209-237).

(1985b). "Roundtable on Translation," in Christie V. McDonald, ed. The Ear of the Other: Otobiography, Transference, Translation. New York, Schocken, pp. 91-161.

FREUD, Sigmund (1977). Die Traumdeutung. Frankfurt, Fischer.

GRAHAM, Joseph F., ed. (1985). Difference in Translation. Ithaca, Cornell.

GREIMAS, Algirdas Julien (1970). Du Sens. Essais sémiotiques. Paris, Gallimard.

HABERMAS, Jürgen (1988). Theorie des kommunikativen Handelns. Frankfurt, Suhrkamp ( 2 vol.). Trad. en fr. (1987) Théorie de l'agir communicationnel. Paris, Fayard.

HEGEL, Georg W.F. (1970). Vorlesungen über die Philosophie der Geschichte. Frankfurt, Suhrkamp.

LEMONNIER, Léon (1928). Les Traducteurs d'Edgar Poe en France de 1845 à 1875: Charles Baudelaire. Paris, Presses universitaires de France.

LÉVI-STRAUSS, Claude (1971). Strukturale Anthropologie. Frankfurt, Suhrkamp. Original: Anthropologie structurale (1958). Paris, Plon.

de MAN, Paul (1986). "'Conclusions': Walter Benjamin's 'The Task of the Translator',"in Paul de Man, The Resistance to Theory. Minneapolis, Univ. of Minnesota Press, pp. 73-105.

MARKIS, Dimitrios (1979). Quine und das Problem der Übersetzung. Freiburg, Alber. 
MESCHONNIC, Henri (1992). "Modernity Modernity," New Literary History, 23, pp. 401-430.

MÜLLER, Klaus Peter (1986). "Culture, Politics, and Values in English Plays of the 1980's. Questions of definition, interpretation, and (self-)knowledge," Englisch-Amerikanische Studien, 3-4, pp. 370-387.

OLSEN, Ole Andkjaer \& Simo KOPPE (1988). Freud's Theory of Psychoanalysis. New York, New York Univ. Press.

PERRAULT, Charles (1964). Parallèle des anciens et des modernes en ce qui regarde les arts et les sciences (ed. Hans Robert Jauss). München, Eidos.

PIA, Pascal (1958). Charles Baudelaire in Selbstzeugnissen und Bilddokumenten. Reinbek, Rowohlt.

PUTNAM, Hilary (1979). Die Bedeutung von "Bedeutung." Frankfurt, Klostermann.

QUINE, Willard van Orman (1960). Word and Object. New York, The Technology Press of M.I.T.

RICCEUR, Paul (1974). Die Interpretation. Ein Versuch über Freud. Frankfurt, Suhrkamp.

SCHLEGEL, Friedrich (1928). "Philosophie der Philologie" (ed. Joseph Körner) Logos. Internationale Zeitschrift für Philosophie der Kultur, XVII, pp. 1-72.

SNELL-HORNBY, Mary (1988). Translation Studies. An Integrated Approach. Amsterdam, John Benjamins.

STEPHAN, Achim (1989). Sinn als Bedeutung. Bedeutungstheoretische Untersuchungen zur Psychoanalyse Sigmund Freuds. Berlin, de Gruyter. 
STURROCK, John (1986). Structuralism. London, Paladin.

TIEDEMANN, Rolf (1973). Studien zur Philosophie Walter Benjamins. Frankfurt, Suhrkamp.

VENUTI, Lawrence, ed. (1992). Rethinking Translation. Discourse, Subjectivity, Ideology. London, Routledge.

WILLIAMS, Raymond (1981). Culture. London, Fontana.

\section{ABSTRACT: Transferring Culture in Translations - Modern} and Postmodern Options - The characteristic elements of the modern theories of translation by Charles Baudelaire and Sigmund Freud are outlined and described in the context of the question of how differences in culture and understanding can be recognized and translated. Translations depend on a certain homogeneity (between the different sign systems used) which can be provided by the creation of meaning through language. The understanding, acknowledgement and creation of meaning is vital for translations. Both Baudelaire and Freud are quite aware of the relative value of such meaning. In postmodernist theories, translation becomes 'necessarily impossible.' Paul de Man's and Jacques Derrida's practical use of Walter Benjamin's text on translation indeed shows that they do not translate him. They do, however, adapt him to their own view and their specific meaning. More and different meanings can be detected in Benjamin, though, and the necessity for multiple, ambiguous, but not entirely arbitrary translations must be recognized. Only a meaningful, inventive combination of one's own and the other's positions can make cultural transfer and the acknowledgement and tentative understanding of otherness possible.

RÉSUMÉ: Le transfert de culture en traduction - Options modernes et postmodernes - Cet article présente les éléments caractéristiques des théories modernes de la traduction de Charles Baudelaire et de Sigmund Freud dans le contexte de la reconnaissance et de la traduction des différences de culture et de 
compréhension. Les traductions dépendent d'une certaine homogénéité (entre les différents systèmes de signes utilisés) qui peut être obtenue par la création du sens au moyen du langage. La compréhension, la reconnaissance et la création du sens sont essentiels à la traduction. Baudelaire tout autant que Freud sont tout à fait conscients de la valeur relative du sens. Avec les théories postmodernes, la traduction devient «nécessairement impossible». L'utilisation pratique que font Paul de Man et Jacques Derrida du texte de Walter Benjamin sur la traduction montre en effet qu'ils ne le traduisent pas. En fait, ils l'adaptent à leur propre perspective et au sens spécifique qui est le leur. On peut certes détecter une pluralité de sens différents chez Benjamin et on doit reconnaître la nécessité d'en réaliser des traductions multiples et ambiguës, mais des traductions qui ne soient pas entièrement arbitraires. Seule une combinaison significative et inventive de sa propre position et de la position de l'autre peut rendre possible le transfert culturel, la reconnaissance et la compréhension exploratoire de l'altérité. 